\title{
A TOOTHED LAURACEAE LEAF FROM THE EARLY EOCENE OF TASMANIA, AUSTRALIA
}

\author{
Raymond J. Carpenter, ${ }^{1, *}$ Gregory J. Jordan, ${ }^{\dagger}$ and Robert S. Hill ${ }^{*, \neq}$
}

*School of Earth and Environmental Sciences, University of Adelaide, SA 5005, Australia; ${ }^{\dagger}$ Department of Plant Science, University of Tasmania, P.O. Box 252-55, Hobart, Tasmania 7001, Australia; and ${ }^{\ddagger}$ Centre for Evolutionary Biology and Biodiversity, South Australian Museum, Adelaide, SA 5000, Australia

${ }^{1}$ Author for correspondence; e-mail raymond.carpenter@adelaide.edu.au

Running head: CARPENTER ET AL.-EARLY EOCENE TOOTHED LAURACEAE 
Bandulskaia aestuaria gen. et sp. nov. is described from Early Eocene estuarine sediments in Tasmania. It is represented by an incomplete leaf with a finely toothed margin and well-preserved cuticle. Despite the absence of such teeth in over 2500 known species of fossil and extant Lauraceae, the fossil cuticle exhibits traits that in combination are only found in the family. These include the derived characters of sunken, paracytic stomata with small, apparently embedded guard cells, stomata confined to small areoles, and stomatal positions that are marked by slit-like abaxial surface apertures, as well as the presence of persistent resin bodies and simple, uniseriate trichomes with thickened, poral bases. Although monimioid teeth occur widely in other lauralean families, the teeth in B. aestuaria are not monimioid, and it is most parsimonious to infer that the teeth were derived independently within Lauraceae, possibly in response to the physiological demands of the warm, waterlogged, high latitude, 'Greenhouse’ environment.

Keywords: Early Eocene, Lauraceae, Laurales, leaf teeth, leaf cuticle, stomata.

\section{Introduction}

The Lauraceae is one of the largest subtropical to tropical families of woody plants, with over 50 genera and 2500 to 3000 species (Rohwer 1993). Phylogenetically, the family forms a monophyletic group with Monimiaceae and Hernandiaceae in the Laurales, but although morphology-based interpretations place Hernandiaceae as sister to Lauraceae (Doyle and Endress 2000), the most recent molecular studies using multiple genes show Hernandiaceae + Monimiaceae as the sister (Qiu et al. 2006). Despite this topological disparity, Laurales is clearly understood on both molecular and morphological evidence to also include Atherospermataceae, Calycanthaceae/Idiospermum, Gomortega and Siparunaceae (Renner 1999; Doyle and Endress 2000; Renner and Chanderbali 2000; Renner 2004). Laurales are sister to Magnoliales and these orders form a near basal angiosperm clade with Canellales and Piperales (Qiu et al. 2006). Relatively abundant 
fossilized foliar and reproductive structures of Lauraceae are known from widespread mid- and Late Cretaceous localities in the Northern Hemisphere (Drinnan et al. 1990; Upchurch and Dilcher 1990; Eklund and Kvacek 1998; Frumin et al. 2004), and well-preserved leaves of Lauraceae are obvious and common components of Cenozoic floras across the globe, where they are widely accepted indicators of warm and wet climates.

The current distribution of Laurales suggests a Gondwanic origin (Rohwer 2000). Australasia is a centre of diversity for Lauraceae with 115 species in seven genera (Hyland 1989), including a strong representation of taxa within 'basal' clades (Rohwer 2000; Chanderbali et al. 2001), especially Cryptocarya. Also, numerous leaf and dispersed cuticle records suggest that the family has had a long history in Australia since at least the Paleocene (Vadala and Greenwood 2001). Fossil leaves assigned to Lauraceae occur Australia-wide, where they appear to be most abundant and diverse in Eocene assemblages. For example, thirteen species have been described from the Middle Eocene Nerriga site (Hill 1986; Conran and Christophel 1998), and at least nine taxa were recognised from leaf and cuticular fragments in the Early Eocene Hotham Heights assemblage (Carpenter et al. 2004).

All known extant species of Lauraceae have simple, entire-margined leaves apart from lobing in Sassafras and Lindera and young foliage of Parasassafras and Sinosassafras (Li and Christophel 2000; Jens Rohwer, personal communication). Lauraceae leaves show a wide diversity of venation, including acrodromous, brochidodromous and camptodromous types (Wolfe 1977; Christophel and Rowett 1996). Overall, this means that fossil leaf impressions cannot be placed in the family with any confidence, and although some such fossils with lobes and large, lobe-like teeth have been assigned to Lauraceae (Johnson 1996), no toothed species have previously been described that are supported by cuticular evidence.

Hill (1986) summarized the history of taxonomic approaches with respect to fossil leaves that might be referable to Lauraceae, and concluded that the form genus Laurophyllum Goeppert "should be used for all fossil leaves which belong to the Lauraceae, but which cannot be placed in a living genus". Hill's (1986) emended diagnosis for the genus emphasized the following cuticular features: 1) paracytic stomata with cuticular scales between the small, embedded guard cells and overarching subsidiary cells (following Bandulska 1926), and 2) 
slit-like stomatal openings on the outer abaxial surface. A further, non-obligatory inclusion in the diagnosis was the presence of resinous secretory cells that can often be observed as yellowish to dark spherical bodies that adhere to the cuticle (Berry 1916; Bandulska 1929; Dilcher 1963). Although the presence of such distinctive cuticular features is strong evidence for Lauraceae, little previous research has evaluated the phylogenetic worth of these characters. Thus, only Upchurch and Dilcher (1990) attempted to identify whether or not foliar characters in Lauraceae were derived (and therefore helpful in excluding extinct or unknown lineages). They postulated that within Laurales, extant Lauraceae show a unique, derived combination of two features that could be interpreted from leaf cuticles: the type of stomata described above, and relatively strong higher order vein areolation.

Apart from the need to further explore the utility of cuticular traits with respect to phylogenies published since the work of Upchurch and Dilcher (1990), it is apparent that some aspects of Lauraceae stomatal anatomy require clarification. In particular, Bandulska (1926), Hill (1986) and Christophel et al. (1996) all presented stylized diagrams that are incorrect in showing the guard cells positioned entirely below the subsidiary cells, and without inner cuticular ledges. In fact, transverse sections of Lauraceae stomatal complexes show that the guard cells are embedded in the mid-region of the ventral walls of the overarching subsidiary cells and have quite prominent inner ledges (Faggetter 1987; Edwards 1990; see fig. 1).

In this paper we further assess aspects of leaf and cuticular morphology pertaining to phylogeny in Lauraceae and related taxa in order to justify the placement of a toothed leaf from the Early Eocene of Tasmania in Lauraceae. The fossil is assigned to a new genus because the diagnosis of Laurophyllum prescribes entire margins (Hill 1986).

\section{Material and Methods}


Early Eocene sediments containing plant fossils are widespread in the Strahan region of Macquarie Harbour, western Tasmania, Australia (Pole 1998; Jordan and Hill 2002). The specimen was recovered from a new site on Lowana Rd, Regatta Point, as part of a collection of fossil material made by G. J. Jordan in 2003. Microfossils in this material include saltwater dinoflagellates and an extremely diverse pollen/spore flora dominated by angiosperms (Macphail 2005). These offer correlative evidence for the age of the sediments from both marine and terrestrial microfossil schema. Based on these, the sediments containing the fossils are most likely to belong to the Upper Malvacipollis diversus Zone of Stover and Partridge (1973), and more or less correlate with the mid Ypresian or Planktonic Foraminiferal Zone P7 of Hardenbol et al. (1998) (Macphail 2005). This implies that the sediments were deposited approximately 52 - 51 million years ago, at or near the height of the Early Eocene Climatic Optimum when 'Greenhouse' conditions are considered to have prevailed worldwide (Zachos et al. 2001). At this time Australia was connected to Antarctica through the Tasmanian region, and western Tasmania would have represented the eastern extent of a long, shallow embayment between these landmasses.

The fossils are currently the subject of a wider study, but include Lygodium (Schizaeaceae), Bowenia (Zamiaceae), Cupressaceae, several species of Araucariaceae and Podocarpaceae respectively, and Gymnostoma (Casuarinaceae), Ripogonum (Ripogonaceae), Proteaceae and other Lauraceae (Carpenter, Jordan and Hill, unpublished data). Pollen of the mangrove palm Nypa is common (Macphail 2005), and as for other sites in the Strahan region (Pole and Macphail 1996; Pole 1998) this strongly suggests that the sediments were deposited in a quiet-water estuarine setting with tidal influence. The association of Nypa and other taxa with nearest living relatives in modern tropical lowlands has been used as evidence that coastal vegetation in the region had a megatherm character (Macphail et al. 1994). According to Nix's (1982) model, megatherm elements now dominate rainforests in the Australia/Papua New Guinea region where mean annual temperatures exceed $24^{\circ} \mathrm{C}$, having optimal temperatures for photosynthesis of $26-28^{\circ} \mathrm{C}$. 
The specimen that is the subject of the present study, LO 49, was recognized as lauraceous by examination of its well-preserved cuticle. Fragments of organic material were first placed in hydrofluoric acid overnight to remove adherent siliceous material. Cuticles were then prepared for both light microscopy (LM) and scanning electron microscopy (SEM) by placing the leaf fragments in $10 \%$ chromium trioxide to clear the mesophyll, followed by a rinse in water. These cuticles were then either further rinsed with dilute ammonia, stained with Safranin O and mounted on glass slides in phenol glycerin jelly for LM, or mounted flat on double sided adhesive tape on an aluminium SEM stub, and gold/carbon coated. SEM was performed using a Philips XL 30 FEGSEM operated at 10kV. For LM, cuticles were photographed using an Olympus DP11 digital camera attached to a Zeiss Axioskop microscope. The leaf specimen was photographed with a Nikon Coolpix 5000 digital camera.

Leaf architectural description is based on Hickey and Wolfe (1975), Hickey (1979) and Leaf Architecture Working Group (1999). Leaves and cuticles from numerous taxa of Lauraceae were studied using fresh material and the collection housed in the School of Earth and Environmental Sciences, University of Adelaide (Table 1). Pieces of leaf of some species (Table 1) were also cut using a freeze microtome to obtain transverse sections approximately $20 \mu \mathrm{m}$ thick. Longitudinal sections of photosynthetic stems of the almost leafless parasite Cassytha pubescens were obtained with the same methods. These sections were stained with a saturated ethanoic solution of the cuticle specific stain, Sudan III. Overall, the species examined occupy widely divergent positions across extant clades of Lauraceae according to the most recent phylogenetic analyses (Rohwer and Rudolph 2005). Some comparisons of tooth and cuticle morphology were also made using leaves of other Laurales (Table 1) to help determine whether the characteristic cuticular character states of Lauraceae are plesiomorphic or apomorphic. This approach essentially follows that of Upchurch and Dilcher (1990), so that unique combinations of apomorphic states are assumed to be good evidence for identifying fossils.

\section{Results}




\title{
Systematics
}

\author{
Order - Laurales \\ Family - Lauraceae \\ Species - Bandulskaia aestuaria Carpenter, Jordan and Hill gen. \& sp. nov.
}

Generic and specific diagnosis. Leaves toothed, hypostomatic. Teeth non-glandular. Stomata paracytic with small, sunken guard cells associated with pronounced cuticular development between guard cells and overarching subsidiary cells. Stomatal openings on outer cuticular surface slit-like. Resin bodies present.

Type species. Bandulskaia aestuaria Carpenter, Jordan and Hill sp. nov.

Etymology. Genus named for Helena Bandulska, whose detailed work highlighted the distinctiveness of Lauraceae stomata. Species named with reference to the presumed estuarine habitat of the source plant.

Holotype. LO 49 here designated (only specimen)

Repository. Specimen - Department of Plant Science, University of Tasmania; Cuticle slides and SEM stubs - School of Earth and Environmental Sciences, University of Adelaide.

Type Locality. Lowana Road, Macquarie Harbour, Tasmania, Australia. Early Eocene mudstone of Macquarie Harbour Formation (Pole 1998).

Description of type. Architecture (fig. 2). Leaf incomplete, $62 \mathrm{~mm}$ long, but estimated to be approximately $100 \mathrm{~mm}$ long, $28 \mathrm{~mm}$ wide, ovate. Margin regularly serrate, at least in the apical portion that is preserved (fig. $2 A, 2 B$ ). Teeth (fig. $2 C$ ) robust, non-glandular, approximately two teeth per secondary vein. Tooth apical angle acute, apical side concave, basal side acuminate. Venation indistinct, but secondary veins appear eucamptodromous, diverging at moderate acute angles from the primary vein, and curved uniformly 
upward, with all visible secondary veins running directly into teeth. Intersecondary and higher order veins not visible.

Cuticular morphology (fig. 3). Abaxial surface. Stomata confined to very small areoles, randomly oriented (fig. $3 A$ ). Stomatal positions marked by longitudinal surface slits approximately $21 \mu \mathrm{m}$ long, with evidence of overarching cuticle associated with subsidiary cells (fig. 3B). Cuticle outer surface otherwise smooth. Stomatal complexes paracytic (fig. $3 C-3 E$ ), approximately $16 \mu \mathrm{m}$ long. Guard cells sunken below overarching subsidiary cells, cuticle with prominent polar extensions (fig. 3D, 3E). Massive cuticular thickenings face pore between guard cells. Irregular-edged cuticular flanges extend laterally between guard and subsidiary cells (fig. $3 E$ ). Inner cuticular anticlinal extensions between epidermal cells straight or rounded, weakly developed except in tooth regions, much more pronounced associated with subsidiary cells (fig. 3D). Poral trichome bases with thickened margins infrequent, mostly along veins (fig. 3A). Trichomes simple, uniseriate, thin walled, approximately $90 \mu \mathrm{m}$ long (fig. $3 F$ ). Resin bodies abundant, darkly stained (fig. $3 G$ ). Adaxial surface. Cuticle outer surface smooth. Inner cuticular anticlinal extensions between epidermal cells straight or rounded (fig. $3 H$, 3I). Gland-like poral trichome bases present, with thick cuticle around pore extending along radial walls of surrounding cells, giving stellate appearance (fig. $3 H$ ). Regions of connected periclinal cuticular thickenings present, especially near leaf margin (fig. 3I).

\section{Discussion}

\section{Characters Used in Identifying Fossil Lauraceae}

The features usually used to identify fossil leaves of Lauraceae are best interpreted as being a mixture of apomorphic and plesiomorphic states. Paracytic stomata are well known to occur throughout the family, but this state alone is of little use for identifying fossils since it is widespread in angiosperms, including Magnoliales and other Laurales (e.g. data in Doyle and Endress 2000). However, as recognized by numerous previous 
authors, the stomata of Lauraceae are quite distinctive. Our transverse leaf sections show that with the exception of Hypodaphnis, Lauraceae stomata follow the general arrangement of being paracytic with sunken guard cells embedded in the ventral walls of the subsidiary cells and bulging between prominent inner and outer cuticular ledges (Table 1; fig. 1A; fig. 4A). These results support previous work by Faggetter (1987, her Fig. 47E) and Edwards (1990). There are many variations in the organization of the stomatal complex in Lauraceae (Bandulska 1926; Dilcher 1963; Hill 1986; Faggetter 1987; Christophel and Rowett 1996), including that further cuticular development is often obvious as variably extensive flanges between the guard cells and overarching subsidiary cells (fig. 4B). These flanges have previously been referred to as scales (e.g. Hill 1986) or lamellae (Upchurch and Dilcher 1990). They appear markedly butterfly-like in many species of Cryptocarya (Christophel and Rowett 1996). Given that the general stomatal arrangement described above is unknown elsewhere in Laurales (see also Upchurch and Dilcher 1990), and not found in Hypodaphnis, which is best interpreted as sister to the rest of Lauraceae (Rohwer and Rudolph 2005), then the most parsimonious interpretation is that this arrangement is a synapomorphy for Lauraceae excluding Hypodaphnis.

A potential problem in conclusively determining fossil stomata as lauraceous is that stomatal anatomy and cuticularization is best interpreted through appropriately stained transverse sections, and it is unlikely that these can be obtained from fossil material. Also, somewhat similar stomatal anatomy to that of Lauraceae occurs in some non-lauralean angiosperms. Metcalfe (1987) described the stomata of Myristicaceae as "paracytic, with guard cells more or less embedded in the subsidiary cells". However, Myristicaceae have complex, distinctively non-lauralean trichome bases (Upchurch and Dilcher 1990). Sunken guard cells embedded in the subsidiary cells and bulging between prominent inner and outer cuticular ledges are also present in Simarouba glauca DC (Simaroubaceae; Sapindales) and many monocots. However, the stomata in $S$. glauca are anomocytic, and monocots can differ from Laurales in many other features.

Our studies support the findings of Upchurch and Dilcher (1990) and Christophel and Rowett (1996) that Lauraceae (apart from Cassytha) have relatively strong higher order vein areolation, with stomata confined to regions sometimes as small as $0.1 \mathrm{~mm}^{2}$ (Table 1). Such areolation only occurs elsewhere in currently 
recognised Laurales in Hernandiaceae subfamily Gyrocarpoideae (Table 1; Upchurch and Dilcher 1990).

Following the topology of Qiu et al. (2006) we therefore conclude that it most parsimoniously arose independently in Lauraceae and Gyrocarpoideae. Similar areolation occurs widely among other angiosperms.

The presence of stomata with slit-like external apertures was included in the diagnosis of Laurophyllum by Hill (1986). Unlike most angiosperms, which have stomatal apertures associated with raised, elliptical regions (or peristomatal rims) formed by the guard cell outer cuticular ledges (see fig. $1 B$ ), the apertures in Lauraceae generally lack rims (fig. $4 C$ ), and appear as slits formed between cuticular extensions of each subsidiary cell (overarching cuticular scales sensu Hill 1986; see fig. 1A). This character is associated with the synapomorphy for Lauraceae (excluding Hypodaphnis) of embedded guard cells, and has not been observed elsewhere in Laurales (see also Metcalfe 1987). Elliptical external rims are evident in some species of Lauraceae (fig. 4D; Hill 1986, his Fig. 6D), and these are probably secondarily derived from subsidiary cell cuticle.

Secretory cells are widely observable in Lauraceae and Monimiaceae as spherical globules adhering to isolated cuticle (Table 1). Oil cells in the mesophyll are also recorded throughout other Laurales and other basal angiosperms excluding Amborella (Metcalfe 1987; Doyle and Endress 2000). We therefore presently regard the presence of these structures in leaves of Laurales as plesiomorphic. The phylogenetic significance of the phenomenon of resin adherence to the cuticle in Lauraceae and Monimiaceae is unclear, and may merely reflect oil cell abundance. Simple, non-glandular trichomes occur throughout Lauraceae (fig. $4 E$ ), where they are often found on veins. They arise from poral bases (fig. $4 E-4 G$ ) that occur at the junction of several cells and that are variously thickened surrounding the pore. The range of base types for Australian species was illustrated by Christophel and Rowett (1996). This type of trichome occurs widely in at least other Laurales (Metcalfe 1987; Table 1), suggesting that it is another plesiomorphic trait in Lauraceae.

Overall, our studies support Upchurch and Dilcher's (1990) proposal that extant Lauraceae show the derived traits of paracytic stomata with embedded guard cells, overarching subsidiary cells, and strong cuticular development between guard and subsidiary cells, as well as relatively well developed higher order vein 
areolation. By implication, the identification of a fossil leaf as Lauraceae should at least demonstrate these features. The presence of slit-like surface apertures is associated with the stomata, but resin bodies and simple, poral-based trichomes are plesiomorphic.

\section{Bandulskaia as Lauraceae}

Despite not being observable in transverse section, the stomata of Bandulskaia clearly show evidence of a synapomorphy for Lauraceae (excluding Hypodaphnis) in being paracytic with very small guard cells overarched by subsidiary cells, and pronounced cuticular development between guard cells and subsidiary cells (e.g. compare figs $3 C$ and $4 B$ ). The fossil stomata also have other derived states in Lauraceae: they are restricted to small, high-order areoles, and open into slit-like apertures on the cuticle surface. Whilst individually each of these features may occur in other angiosperms, we argue that it is very unlikely that all of these structures would occur together in living or extinct lineages outside of Lauraceae. The stomatal anatomy provides evidence that Bandulskaia is nested within extant Lauraceae, because the apparent sister taxon to the rest of the family (Hypodaphnis) expresses the plesiomorphic state.

All other cuticular features of Bandulskaia are consistent with Lauraceae (Table 1). The fossil exhibits relatively unthickened poral trichome bases on the abaxial surface (fig. $3 A, 3 F$ ), and more heavily thickened bases on the adaxial surface (fig. $3 H$ ). Both base types were observed in extant species (fig. $4 F, 4 G$ ). Similarly, a simple, non-glandular trichome found on the abaxial surface of the fossil (fig. $3 F$ ) is clearly comparable with the trichomes of extant species (fig. 4E). Abundant resin bodies adherent to the cuticle are also highly typical of extant Lauraceae. A further, unusual feature of the fossil is that there are regions of irregular but connected, thickened (dark-staining) cuticle on the adaxial surface (fig. 3I). Again, near identical regions were found in the cuticle of an extant species of Cryptocarya (fig. $4 H$ ).

\section{A Toothed Lauraceae}


Leaf teeth are unknown in extant Lauraceae, but monimioid teeth occur widely in most other Laurales (data from Doyle and Endress 2000; Sauquet et al. 2003), and are probably synapomorphic for Laurales, given that Eklund et al. (2004) reassessed the teeth of Trimenia (Trimeniaceae; Austrobaileyales) as chloranthoid and not monimioid, as first determined by Hickey and Doyle (1975). Monimioid teeth have an opaque, sometimes persistent glandular cap having an acute apex, the shape of the tooth being acuminate-convex, and its venation showing a secondary or tertiary vein entering the tooth medially, it not being joined by lateral veins (Hickey and Wolfe 1975; also see fig. 4I). However, the leaf teeth in Bandulskaia lack the glandular caps of monimioid teeth (fig. $2 C$ ). While non-glandular teeth could have evolved from monimioid teeth, they could also have evolved independently. Overall, the latter hypothesis is more parsimonious, given the evidence that Bandulskaia is nested within Lauraceae.

Toothed leaf margins are over-represented among woody plants of wet habitats in general (Kowalski and Dilcher 2003), probably related to teeth being sites that can enable the release of guttation sap during root pressure, thus promoting the avoidance of mesophyll flooding (Feild et al. 2005). This seems an attractive hypothesis for explaining the teeth in Bandulskaia, especially given that the source plant was probably growing in the close vicinity of tidal channels, and thus in wet soil.

Aspects of past climates have been predicted by simply assessing the margin types of leaves in fossil assemblages (e.g. Wing and Greenwood 1993; Greenwood et al. 2004), based on the long-standing observation of a positive correlation between MAT and the proportion of extant woody dicotyledonous species with nontoothed leaf margins (Bailey and Sinnott 1916). Increasingly sophisticated techniques and more data sets derived from modern floras (e.g. Royer et al. 2005) offer the possibility of reducing the magnitude of the inherent limitations (Jordan 1997) associated with this approach. Also, there is greater recognition that climate variables such as growing season length probably influence leaf physiognomy more than MAT per se (Jordan 1997; Royer et al. 2005). Our demonstration of the presence in the Early Eocene of Tasmania of a species of toothed margined Lauraceae associated with cycads and mangroves at $65^{\circ} \mathrm{S}$ serves as a reminder for 
paleoclimatologists that unusual leaf forms are to be expected in past environments that have no modern equivalent (e.g. Hill and Scriven 1995).

\section{Acknowledgments}

We are grateful to Jenny Read (Monash University) and H.-H. Poppendieck (HBG) for forwarding additional leaf material of Laurales, and to Jens Rohwer for comments on Lauraceae leaves. Our work was supported by funding from the Australian Research Council.

\section{Literature Cited}

Bailey IW, E Sinnott 1916 The climatic distribution of certain types of angiosperm leaves. Am J Bot 3:24-39. Bandulska H 1926 On the cuticles of some fossil and recent Lauraceae. Bot J Linn Soc 47:383-425.

Bandulska H 1929 Secretory cells in a fossil leaf. Ann Bot 43:203-204.

Berry EW 1916 The Lower Eocene floras of Southeastern North America. US Geol Surv Prof Pap 91. 481 pp.

Carpenter RJ, RS Hill, DR Greenwood, AD Partridge, MA Banks 2004 No snow in the mountains: Early Eocene plant fossils from Hotham Heights, Victoria, Australia. Aust J Bot 52:685-718.

Chanderbali AS, H van der Werff, SS Renner 2001 Phylogeny and historical biogeography of Lauraceae: evidence from the chloroplast and nuclear genomes. Ann Mo Bot Gard 88:104-134.

Christophel DC, AI Rowett 1996 Leaf and cuticle atlas of Australian leafy Lauraceae. Flora of Australia Supplementary Series Number 6. ABRS Canberra

Christophel DC, R Kerrigan, AI Rowett 1996 The use of cuticular features in the taxonomy of the Lauraceae. Ann Mo Bot Gard 83:419-432.

Conran JG, DC Christophel 1998 A new species of triplinerved Laurophyllum from the Eocene of Nerriga, New South Wales. Alcheringa 22:343-348. 
Dilcher DL 1963 Cuticular analysis of Eocene leaves of Ocotea obtusifolia. Am J Bot 50:1-8.

Doyle JA, PK Endress 2000 Morphological phylogenetic analysis of basal angiosperms: comparison and combination with molecular data. Int J Plant Sci 161 (suppl):S121-S153.

Drinnan AN, PR Crane, EM Friis, KR Pedersen 1990 Lauraceous flowers from the Potomac group (midCretaceous) of eastern North America. Bot Gaz 151:370-384.

Edwards HH 1990 The stomatal complex of Persea borbonia. Can J Bot 68:2543-2547.

Eklund H, J Kvaček 1998 Lauraceous inflorescences and flowers from the Cenomanian of Bohemia (Czech Republic, central Europe). Int J Plant Sci 159:668-686.

Eklund H, JA Doyle, PS Herendeen 2004 Morphological phylogenetic analysis of living and fossil Chloranthaceae. Int J Plant Sci 165:107-151.

Faggetter CD 1987 Leaf cuticles (phytoglyphs) of selected Lauraceae. Pages 157-160 in CR Metcalfe. Anatomy of the dicotyledons. $2^{\text {nd }}$ ed. Vol III. Magnoliales, Illiciales, and Laurales. Clarendon Press, Oxford.

Feild TS, TL Sage, C Czerniak, WJD Iles 2005 Hydathodal leaf teeth of Chloranthus japonicus (Chloranthaceae) prevent guttation-induced flooding of the mesophyll. Plant Cell Env 28:1179-1190.

Frumin S, H Eklund, AM Friis 2004 Mauldinia hirsuta sp. nov., a new member of the extinct genus Mauldinia (Lauraceae) from the Late Cretaceous (Cenomanian-Turonian) of Kazakhstan. Int J Plant Sci 165:883895.

Greenwood DR, P Wilf, SL Wing, DC Christophel 2004 Paleotemperature estimation using leaf-margin analysis: is Australia different? Palaios19:129-142.

Hardenbol J, J Thierry, MB Farley, T Jacquin, P-C de Graciansky, PR Vail 1998 Mesozoic and Cenozoic sequence chronostratigraphic framework of European basins. Pages 3-14 in P-C de Graciansky, J Hardenbol, T Jacquin, PR Vail, eds. Mesozoic and Cenozoic sequence stratigraphy of European basins. SEPM Spec. Publn. 60. 
Hickey LJ 1979 A revised classification of the architecture of dicotyledonous leaves. Pages 25-39 in CR Metcalfe, L Chalk, eds. Anatomy of the dicotyledons. $2^{\text {nd }}$ ed. Vol I. Systematic anatomy of leaf and stem, with a brief history of the subject. Clarendon Press, Oxford.

Hickey LJ, JA Wolfe 1975 The bases of angiosperm phylogeny: vegetative morphology. Ann Mo Bot Gard 62:538-589.

Hill RS 1986 Lauraceous leaves from the Eocene of Nerriga, New South Wales. Alcheringa 10:327-351.

Hill RS, LJ Scriven 1995 The angiosperm-dominated woody vegetation of Antarctica: a review. Rev Palaeobot Palynol 86:175-198.

Hyland BPM 1989 A revision of Lauraceae in Australia (excluding Cassytha). Aust Syst Bot 2:135-367.

Johnson KR 1996 Description of seven common fossil leaf species from the Hell Creek Formation (Upper Cretaceous: Upper Maastrichtian). North Dakota, South Dakota, and Montana. Proc Denver Mus Nat Hist, Ser 3, 12:1-47.

Jordan GJ 1997 Uncertainty in palaeoclimatic reconstructions based on leaf physiognomy. Aust J Bot 45:527547.

Jordan GJ, RS Hill 2002 Cenozoic macrofossil sites of Tasmania. Pap Proc Roy Soc Tas 136:127-139.

Kowalski EA, DL Dilcher 2003 Warmer paleotemperatures for terrestrial ecosystems. PNAS 100:167-170.

Leaf Architecture Working Group 1999 Manual of Leaf Architecture - morphological description and categorization of dicotyledonous and net-veined monocotyledonous angiosperms. Smithsonian Institution, Washington DC. 65 pp.

Li J, DC Christophel 2000 Systematic relationships within the Litsea complex (Lauraceae): a cladistic analysis based on morphological and leaf cuticle data. Aust Syst Bot 13:1-13.

Macphail MK 2005 Palynostratigraphic analysis of plant microfossils preserved in Early Eocene mudstones at Lowana Road, Strahan, west coast of Tasmania. (Report $\bigodot$ prepared for R.S.H. \& R.J.C.) Consultant Palynological Services, Aranda, ACT.

Macphail MK, NF Alley, EM Truswell, IRK Sluiter 1994 Early Tertiary vegetation: evidence from spores and 
pollen. Pages 189-261 in RS Hill, ed. History of the Australian vegetation: Cretaceous to recent. Cambridge University Press, Cambridge.

Metcalfe CR 1987 Anatomy of the dicotyledons. 2nd ed. Vol. III. Magnoliales, Illiciales, and Laurales. Clarendon, Oxford. 224 pp.

Nix HA 1982 Environmental determinants of biogeography and evolution in Terra Australis. Pages 47-66 in WR Barker, PJM Greenslade, eds. Evolution of the flora and fauna of arid Australia. Peacock Publications, Adelaide.

Pole MS 1998 Early Eocene estuary at Strahan, Tasmania. Aust J Earth Sci 45:979-985.

Pole MS, MK Macphail 1996 Eocene Nypa from Regatta Point, Tasmania. Rev Palaeobot Palynol 92:55-67.

Qiu Y-L, L Li, TA Hendry, R Li, DW Taylor, MJ Issa, AJ Ronen, ML Vekaria, AM White 2006. Reconstructing the basal angiosperm phylogeny: Evaluating information content of mitochondrial genes. Taxon 55:837-856.

Renner SS 1999 Circumscription and phylogeny of the Laurales: evidence from molecular and morphological data. Am J Bot 86:1301-1315.

Renner SS 2004 Variation in diversity among Laurales, Early Cretaceous to present. Biol Skr 55:441-458.

Renner SS, AS Chanderbali 2000 What is the relationship among Hernandiaceae, Lauraceae, and Monimiaceae, and why is the question so difficult to answer? Int J Plant Sci 161(6 Suppl.):S109-S119.

Rohwer JG 1993 Lauraceae. Pages 366-391 in K. Kubitzki, JG Rohwer, V Bittrich, eds. The families and genera of vascular plants, Vol. 2. Springer Verlag, Berlin.

Rohwer JG 2000 Toward a phylogenetic classification of the Lauraceae: evidence from matK sequences. Syst Bot 25:60-71.

Rohwer JG, B Rudolph 2005 Jumping genera: the phylogenetic positions of Cassytha, Hypodaphnis and Neocinnamomum (Lauraceae) based on different analyses of trnK intron sequences. Ann Mo Bot Gard 92:153-178.

Royer DL, P Wilf, DA Janesko, EA Kowalski, DL Dilcher 2005 Correlations of climate and plant ecology to 
leaf size and shape: potential proxies for the fossil record. Am J Bot 92:1141-1151.

Sauquet H, JA Doyle, T Scharaschkin, T Borsch, KW Hilu, LW Chatrou, A le Thomas 2003 Phylogenetic analysis of Magnoliales and Myristicaceae based on multiple data sets: implications for character evolution. Bot J Linn Soc 142:125-186.

Stover LE, AD Partridge 1973 Tertiary and Late Cretaceous spores and pollen from the Gippsland Basin, southeastern Australia. Proc Roy Soc Vic 85:237-286.

Upchurch GR, DL Dilcher 1990 Cenomanian angiosperm leaf megafossils, Dakota Formation, Rose Creek locality, Jefferson County, southeastern Nebraska. US Geol Soc Bull 1915. 55 pp.

Vadala AJ, DR Greenwood 2001 Australian Paleogene vegetation and environments: evidence for paleoGondwanic elements in the fossil records of Lauraceae and Proteaceae. Pages 196-221 in I Metcalfe, JMB Smith, I Davidson, eds. Faunal and floral migrations and evolution in SE Asia-Australasia. Swets \& Zeitlinger Publishers, Lisse.

Wing SL, DR Greenwood 1993 Fossils and fossil climates: the case for equable continental interiors in the Eocene. Phil Trans Roy Soc Lond Ser B 341:243-252.

Wolfe JA 1977 Paleogene floras from the Gulf of Alaska region. US Geol Surv Prof Pap 997. 108 pp.

Zachos JC, M Pagani, L Sloan, E Thomas, K Billups 2001 Trends, rhythms, and aberrations in global climate 65 Ma to present. Science 292:686-693. 
Fig. 1 Stylized transverse sections through stomata. A, Lauraceae (general form). Note the guard cells sunken below the leaf surface and embedded in the subsidiary cells, and way that each guard cell bulges between the inner and outer cuticular ledges. The extent of cuticularization is variable, and not shown, but cuticle between the guard cells and subsidiary cells is typically obvious in the region of the outer ledges as laterally extending flanges. B, Atherosperma moschatum (Atherospermataceae; Laurales), showing features widespread in other angiosperms. Note that the guard cells are not embedded in the subsidiary cells, and do not bulge markedly between the inner and outer cuticular ledges.

Fig. 2 Holotype of Bandulskaia aestuaria. Scale bars $=1 \mathrm{~cm}$ for $A ; 500 \mu \mathrm{m}$ for $C$. A, Whole specimen showing upwardly curving secondary veins. $B$, Enlargement showing positions of leaf teeth. A preserved robust tooth apex is arrowed. $C$, SEM image of detached tooth apex. Note absence of glandular tip.

Fig. $3 \mathrm{LM}(A, C, F-I)$ and $\operatorname{SEM}(B, D, E)$ images of Bandulskaia aestuaria. Scale bars $=100 \mu \mathrm{m}$ for $A ; 50 \mu \mathrm{m}$ for $B ; 10 \mu \mathrm{m}$ for $C ; 20 \mu \mathrm{m}$ for $D, F, G ; 5 \mu \mathrm{m}$ for $E, 25 \mu \mathrm{m}$ for $H, I . A$, General view of abaxial cuticle showing stomata in an areole, and several poral trichome bases on veins. $B$, Outer abaxial cuticle showing slits that lead to stomata, and evidence of overarching subsidiary cells. $C$, Individual paracytic stoma, showing stomatal slit and cuticular development between guard and subsidiary cells. $D$, Inner surface of abaxial cuticle showing stomata. Note that anticlinal cuticle flanges of epidermal walls are only well developed where associated with subsidiary cells. $E$, Detail of inner stomatal complex showing evidence of sunken guard cells and overarching subsidiary cells. Note polar cuticular extensions, inner thickenings surrounding pore, and cuticular flanges with irregular edges between guard and subsidiary cells. $F$, Thin-walled simple trichome arising from poral base on abaxial vein. $G$, Dense resin body adherent to inner abaxial cuticle. $H$, Adaxial cuticle showing thickened poral trichome base with stellate appearance. I, Adaxial cuticle showing connected regions of periclinal thickenings.

Fig. 4 LM $(A, B, E-H)$ and SEM $(C, D)$ images of extant Lauraceae cuticle and SEM image of Laureliopsis 
philippiana leaf tooth $(I)$. Scale bars $=20 \mu \mathrm{m}$ for $A ; 5 \mu \mathrm{m}$ for $B ; 50 \mu \mathrm{m}$ for $C, D, F, H ; 10 \mu \mathrm{m}$ for $E ; 25 \mu \mathrm{m}$ for G; $200 \mu \mathrm{m}$ for I. A, Transverse section through Laurus nobilis stomatal complex. Regions stained red with Sudan III (i.e. cuticularized) are outlined. Note that the subsidiary cells (s) extend both above and below the embedded guard cells (g). Also note outer and inner (one of pair arrowed) guard cell cuticular ledges. $B$, Individual paracytic stoma of Beilschmiedia gemiflora showing cuticular development between guard and subsidiary cells. $C$, Outer abaxial surface of Beilschmiedia bancroftii showing a small areole with stomatal positions marked by slit-like apertures and poral trichome bases on veins. $D$, Outer abaxial surface of Cryptocarya angulata showing raised elliptical rims surrounding stomata. $E$, Thin-walled simple trichome arising from poral base on abaxial vein of Cryptocarya glaucescens. F, General view of stomata of Endiandra virens with a poral trichome base on vein at upper left. $G$, Adaxial cuticle of Endiandra crassifolia showing thickened poral trichome base with stellate appearance. H, Adaxial cuticle of Cryptocarya obovata showing connected regions of periclinal thickenings. I, Tooth apex showing prominent monimioid glandular cap.

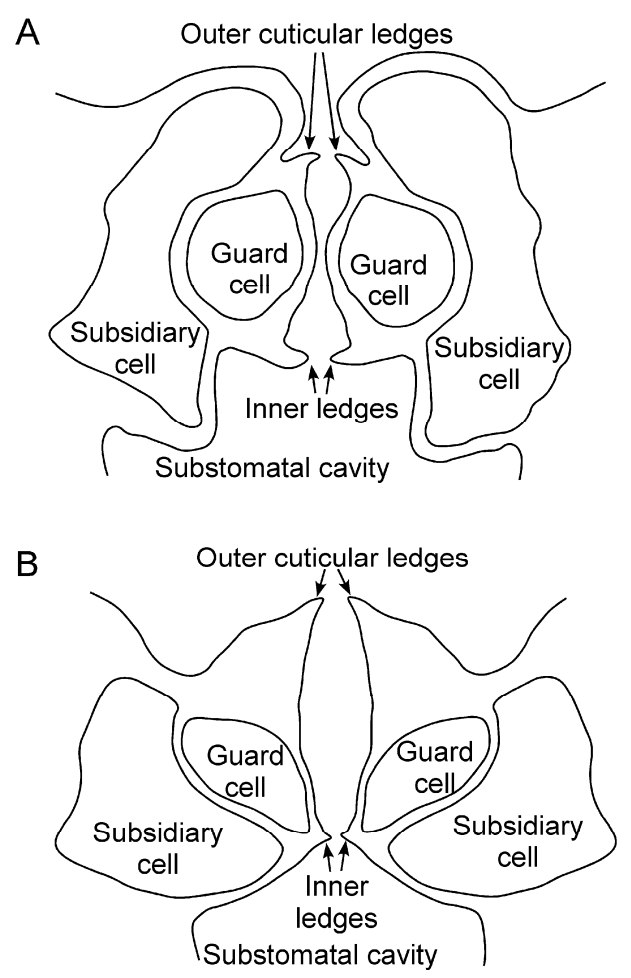



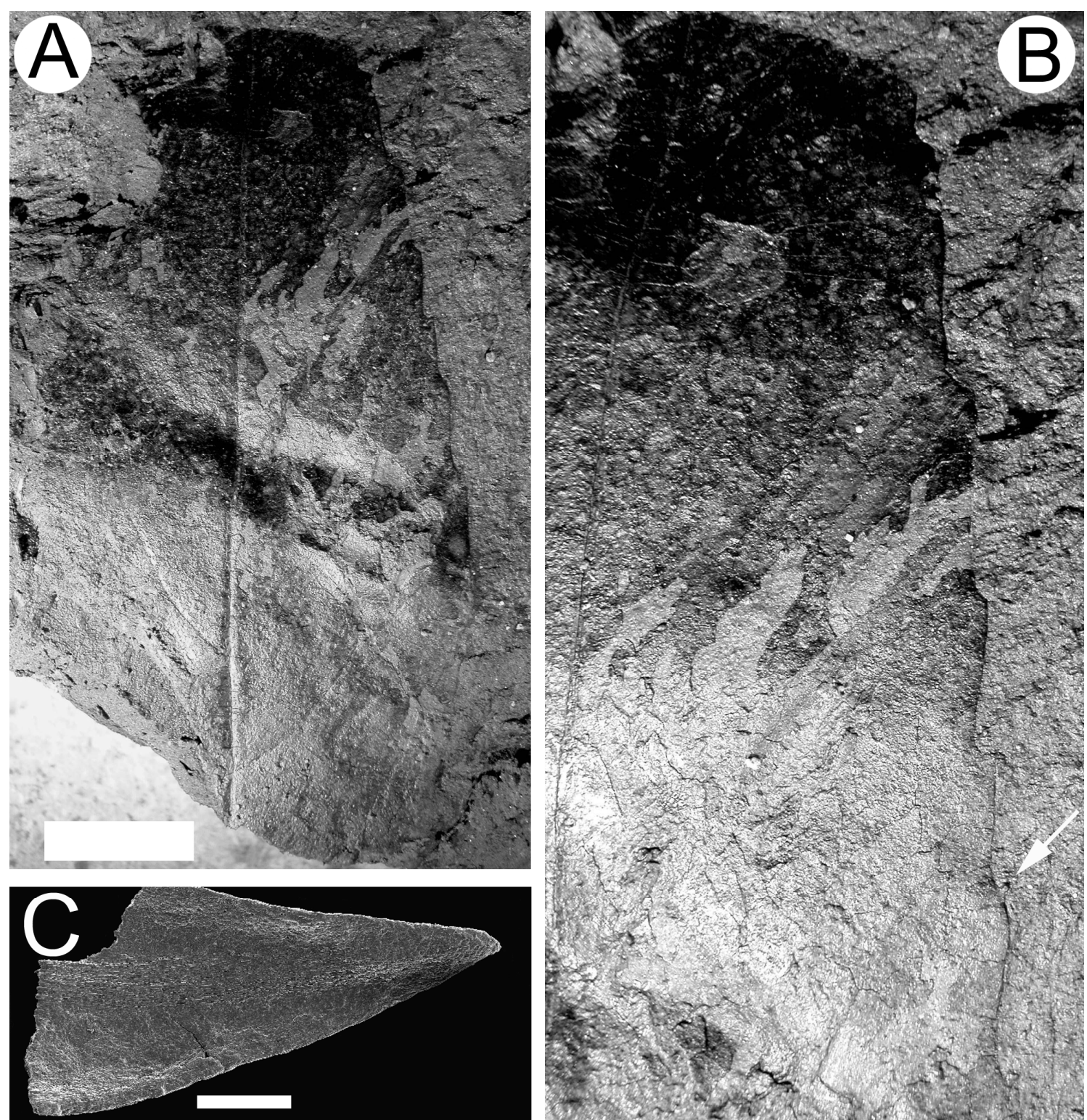

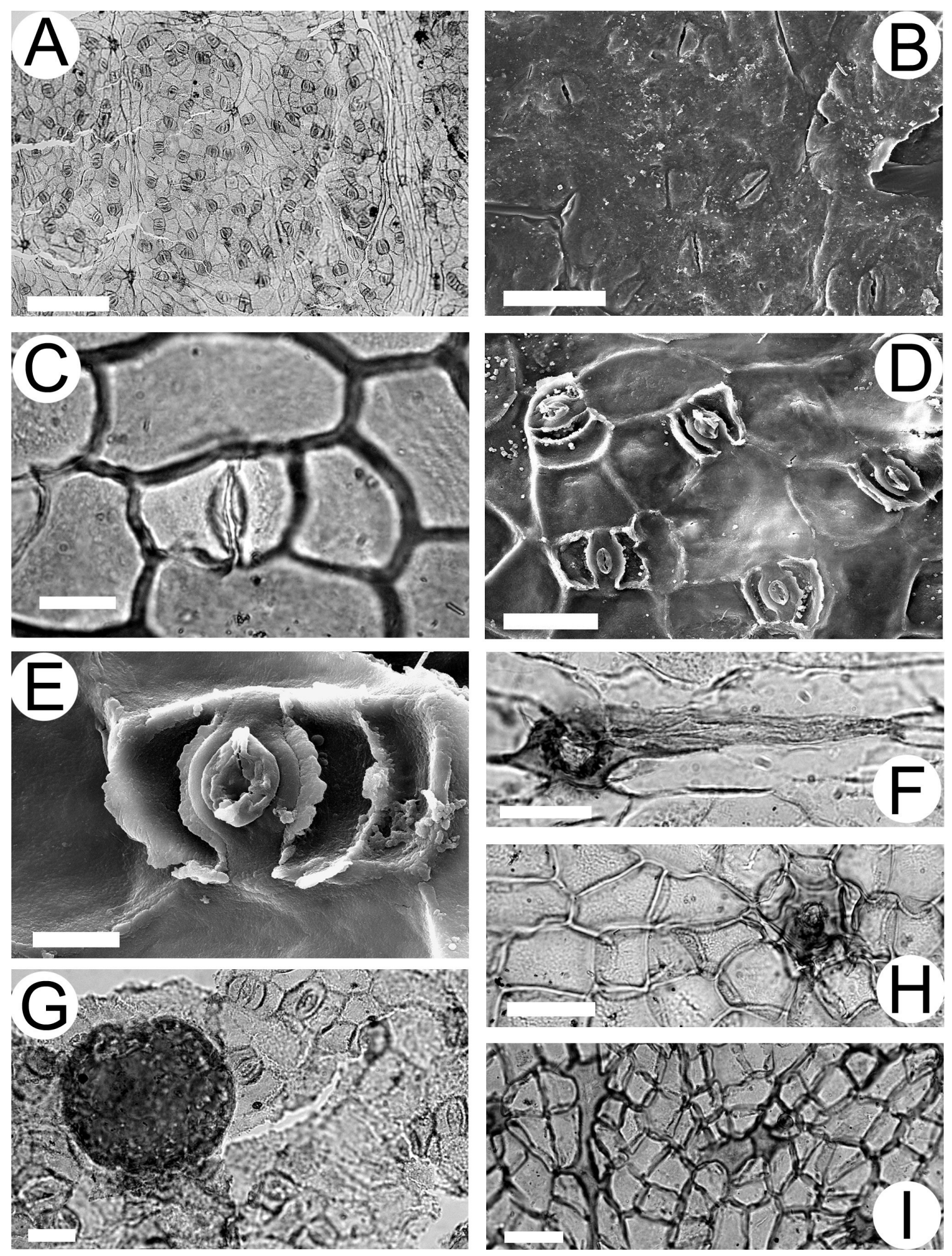

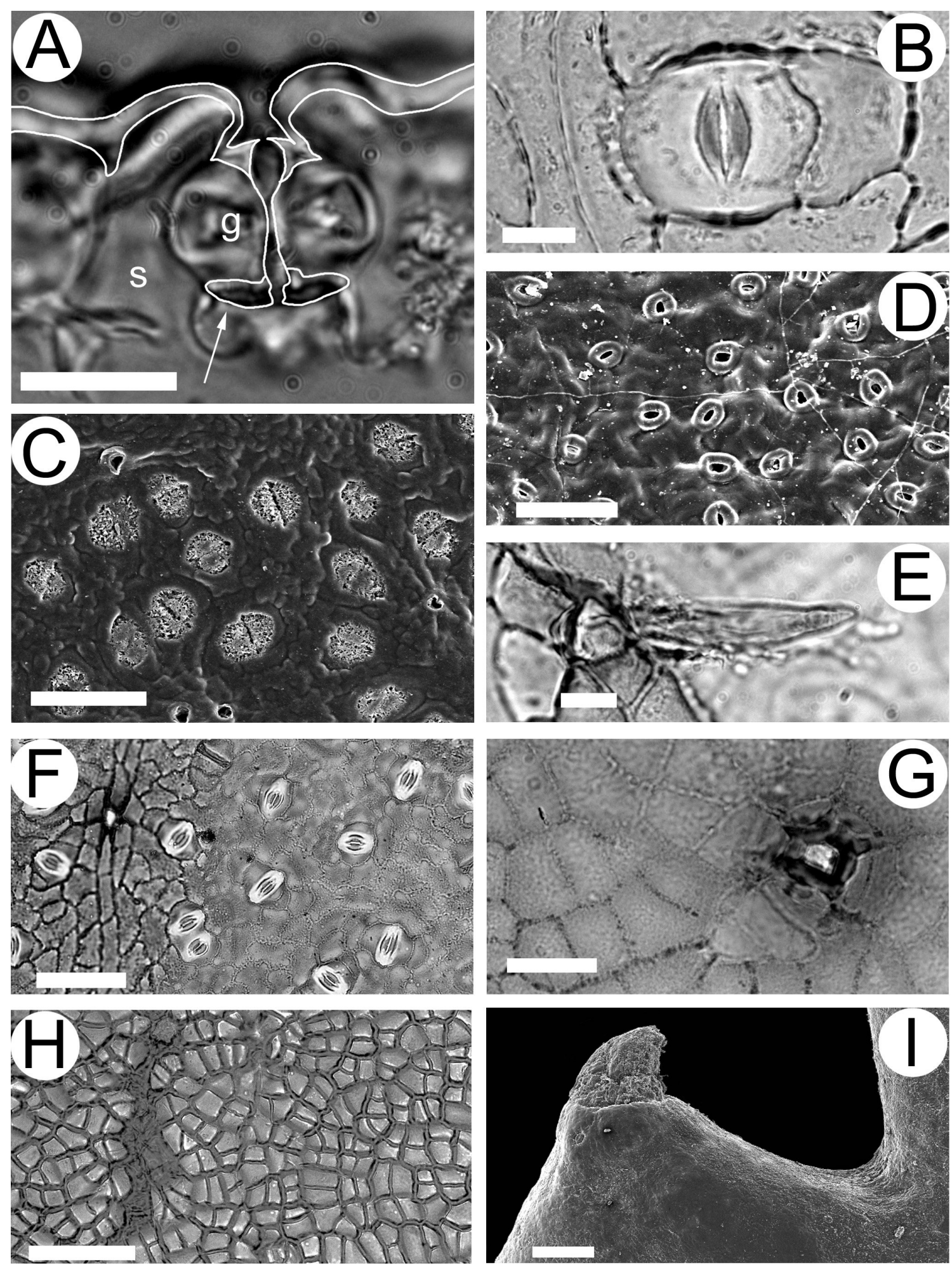


\section{Table 1}

\section{List of Laurales species examined in detail}

\begin{tabular}{|c|c|c|c|c|c|c|}
\hline & 1 & 2 & 3 & 4 & 5 & 6 \\
\hline \multicolumn{7}{|l|}{ Atherospermataceae } \\
\hline Atherosperma moschatum Labill. & $\mathrm{E} / \mathrm{CM} / 010$ & no & no & anomocytic & simple & \\
\hline Daphnandra micrantha (Tul.) Benth. & M. Pole OPH1323 & no & no & anomocytic & simple & \\
\hline Doryphora sassafras Endl. & $\mathrm{E} / \mathrm{DO} / 037$ & no & no & anomocytic & simple & \\
\hline Laureliopsis philippiana (Looser) Schodde & $\mathrm{E} / 3128$ & no & ?yes & paracytic & simple & \\
\hline \multicolumn{7}{|l|}{ Calycanthaceae } \\
\hline Idiospermum australiensis (Diels) S. T. Blake & M. Pole OPH1615 & no & no & paracytic & simple & \\
\hline \multicolumn{7}{|l|}{ Hernandiaceae } \\
\hline Gyrocarpus americanus Jacq. & CANB 464883 & yes* & no & ?paracytic & simple & \\
\hline Hernandia albiflora (C. White) Kubitzki & cultivated Brisbane & no & no & ?anomocytic & glandular & \\
\hline Hernandia bivalvis Benth. & Adelaide Botanical Gardens & no & no, TSN & paracytic & glandular & \\
\hline \multicolumn{7}{|l|}{ Lauraceae } \\
\hline fossil Bandulskaia aestuaria & & yes* & yes & paracytic & simple & yes \\
\hline Beilschmiedia bancroftii (F. M. Bailey) C. T. White & LAE 230499, E/0158 & yes* & yes & paracytic & simple & \\
\hline B. dilmyana Kosterm. & $\mathrm{E} / 0162$ & yes & yes & paracytic & simple & \\
\hline B. gemiflora (B1.) Kosterm. & $\mathrm{E} / 0163$ & yes & yes & paracytic & simple & \\
\hline B. obtusifolia (F. Muell. Ex Meisn.) F. Muell. & Sydney Botanical Gardens & yes & yes, TSE & paracytic & simple & \\
\hline Cassytha pubescens $\mathrm{R}$. Br. & University of Tasmania & no & yes, TSE & paracytic & & \\
\hline Cinnamomum archboldianum C. K. Allen & LAE 19224, E/0177 & yes & yes & paracytic & simple & \\
\hline C. culilawan $\mathrm{B}$. & LAE $2632, \mathrm{E} / 0216$ & yes & yes & paracytic & simple & \\
\hline C. hentyi Kosterm. & LAE 112121, E/0179 & yes* & yes & paracytic & simple & \\
\hline C. oliveri F. M. Bailey & LAE 230867, E/0187 & yes & yes & paracytic & simple & yes \\
\hline Crytpocarya angulata C. T. White & E/0204 & yes & yes & paracytic & simple & \\
\hline C. glaucescens $\mathrm{R} . \mathrm{Br}$. & LAE 222127, E/0237 & yes* & yes & paracytic & simple & \\
\hline C. meissneriana Frodin & $\mathrm{E} / \mathrm{DO} / 030$ & yes & yes & paracytic & simple & \\
\hline C. obovata $\mathrm{R} . \mathrm{Br}$. & $\mathrm{E} / 1125$ & yes & yes & paracytic & simple & \\
\hline C. triplinervis $\mathrm{R}$. Br. & Sydney Botanical Gardens & yes & yes, TSE & paracytic & simple & \\
\hline Endiandra crassifolia $\mathrm{C}$. T. White \& W. D. Francis & M. Pole OPH1300 & yes & yes & paracytic & simple & \\
\hline E. glauca $\mathrm{R} . \mathrm{Br}$. & LAE 221745, E/0332 & yes & yes & paracytic & simple & \\
\hline E. virens $\mathrm{F}$. Muell. & $\mathrm{E} / 1129$ & yes & yes & paracytic & simple & \\
\hline Hypodaphnis zenkeri (Engl.) Stapf & HBG G. Zenker 3033 & yes & no, TSN & paracytic & simple & yes \\
\hline Laurus nobilis L. & Adelaide Bot. Gard., E/1167 & yes* & yes, TSE & paracytic & simple & \\
\hline Lindera benzoin (L.) Blume & KUN 0049334, E/3856 & yes & yes & paracytic & simple & yes \\
\hline Litsea bindoniana (F. Muell.) F. Muell. & Sydney Botanical Gardens & yes & yes, TSE & paracytic & simple & \\
\hline L. leefeana (F. Muell.) Merr. & LAE 230944, E/0422 & yes* & yes & paracytic & simple & \\
\hline Neolitsea dealbata (R. Br.) Merr. & $\mathrm{E} / \mathrm{BB} / 024$ & yes & yes & paracytic & simple & \\
\hline Persea borbonia (L.) K. Spreng. & LAE 83340, E/0453 & yes* & yes & paracytic & simple & \\
\hline Sassafras albidum (Nutt.) Nees & K. Holland 42, E/M/130 & yes & yes & paracytic & simple & \\
\hline
\end{tabular}


Monimiaceae

Hedycarya angustifolia A. Cunn.

Levieria acuminata (F. Muell.) J. R. Perkins

Adelaide Botanical Gardens no

no, TSN paracytic

simple yes

Palmeria scandens F. Muell.

JCT/S7114

no

no

paracytic

simple yes

Steganthera laxiflora (Benth.) Foreman \& Whiffin JCT/S994

no no

anomocytic

stellate yes

Wilkiea hugeliana (Tul.) A. DC.

$\mathrm{JCT} / \mathrm{s} 6152 \mathrm{a}$

no

paracytic

simple yes

no ?yes paracytic simple yes

Note. 1, source/University of Adelaide cuticle number; 2, well defined areoles $\left(*=\right.$ very small, $\left.\sim 1 \mathrm{~mm}^{2}\right) ; 3$, prominent cuticular development between guard and subsidiary cells $(\mathrm{TSE}=$ transverse section clearly shows guard cells embedded in subsidiary cells; TSN= not embedded); 4, subsidiary cell arrangement; 5, trichome type; 6 , resin adherent to cuticle. 